Review

\title{
Application of Remote Sensors in Mapping Rice Area and Forecasting Its Production: A Review
}

\author{
Mostafa K. Mosleh, Quazi K. Hassan * and Ehsan H. Chowdhury \\ Department of Geomatics Engineering, Schulich School of Engineering, University of Calgary, \\ 2500 University Dr NW, Calgary, Alberta T2N 1N4, Canada; E-Mails: mkkmosle@ucalgary.ca (M.K.M.); \\ echowdhu@ucalgary.ca (E.H.C.) \\ * Author to whom correspondence should be addressed; E-Mail: qhassan@ucalgary.ca; \\ Tel.: +1-403-210-9494; Fax: +1-403-284-1980.
}

Academic Editor: Assefa M. Melesse

Received: 7 November 2014 / Accepted: 29 December 2014 / Published: 5 January 2015

\begin{abstract}
Rice is one of the staple foods for more than three billion people worldwide. Rice paddies accounted for approximately $11.5 \%$ of the World's arable land area during 2012. Rice provided $\sim 19 \%$ of the global dietary energy in recent times and its annual average consumption per capita was $\sim 65 \mathrm{~kg}$ during 2010-2011. Therefore, rice area mapping and forecasting its production is important for food security, where demands often exceed production due to an ever increasing population. Timely and accurate estimation of rice areas and forecasting its production can provide invaluable information for governments, planners, and decision makers in formulating policies in regard to import/export in the event of shortfall and/or surplus. The aim of this paper was to review the applicability of the remote sensing-based imagery for rice area mapping and forecasting its production. Recent advances on the resolutions (i.e., spectral, spatial, radiometric, and temporal) and availability of remote sensing imagery have allowed us timely collection of information on the growth and development stages of the rice crop. For elaborative understanding of the application of remote sensing sensors, following issues were described: the rice area mapping and forecasting its production using optical and microwave imagery, synergy between remote sensing-based methods and other developments, and their implications as an operational one. The overview of the studies to date indicated that remote sensing-based methods using optical and microwave imagery found to be encouraging. However, there were having some limitations, such as: (i) optical remote sensing imagery had relatively low spatial resolution led to inaccurate estimation of rice areas; and (ii) radar imagery would suffer from speckles,
\end{abstract}


which potentially would degrade the quality of the images; and also the brightness of the backscatters were sensitive to the interacting surface. In addition, most of the methods used in forecasting rice yield were empirical in nature, so thus it would require further calibration and validation prior to implement over other geographical locations.

Keywords: microwave remote sensing; optical remote sensing; rice acreage mapping; rice yield forecasting

\section{Introduction}

Rice is one of the most important crop/food for more than three billion people (i.e., approximately $50 \%$ of the World's population) [1]. During 2012, rice was cultivated on about $11.5 \%$ of the World's arable land; i.e., 160.5 million hectares of land was under rice [2], while the total arable land was $\sim 1395$ million hectares [3]. It is usually grown almost everywhere in the World, and its production in 2012 was $\sim 730$ million tonnes [2]. However, most of the rice (i.e., $\sim 88 \%$ of the World's total production in 2010 [4]) has been grown in Asia where $\sim 60 \%$ of the World's population lives [5]. Among the prominent rice-producing countries, the seven largest producers were China (197.22 million tonnes), India (120.62 million tonnes), Indonesia (66.41 million tonnes), Bangladesh (49.36 million tonnes), Viet Nam (39.99 million tonnes), Myanmar (33.20 million tonnes), and Thailand (31.56 million tonnes); which accounted together for $\sim 80.12 \%$ of the 2010 World production [4]. In recent times, rice has provided $\sim 19 \%$ of the global dietary energy [6] and its annual average consumption per capita during 2010-2011 was $\sim 65 \mathrm{~kg}$ [7].

Despite the large global cultivated rice area and growing rice production in many countries, the total demands often exceed the production. In addition, the global rice consumption is projected to be $\sim 873$ million tonnes in 2030 [8]. In the recent decades, two major issues like population growth (in particular in the major rice producing/consuming countries) [5] and climate change put enormous pressure on the global food demand and its production $[9,10]$. Since problems with food security persist in many areas of the World [9], in particular in the heavy rice consuming regions, robust and reliable tools for mapping and early forecasting of rice production are thus critical. This is the case as reliable and timely estimates of rice crop areas and its production are essential for providing information for planners and decision makers to formulate policies in the case of shortfall or surplus.

It is interesting to mention that the most common and widely used methods for estimating rice cultivated areas are the use of agricultural statistical data acquired through field visits and interviewing the farmers. The methodology for mapping area under rice cultivation is basically done through annual/seasonal sample surveys based on a number of sample clusters that are constituted all over the country for measuring cultivated area during the crop growing season. Each cluster is visited many times and areas are recorded by the field staffs, checked, and then processed by regional statistical officers. Despite its invaluable ability for understanding historical trends in rice area, this method is extremely tedious, time-consuming, less precise, costly, inconsistent, and labour-intensive $[11,12]$.

On the other hand, in terms of yield/production forecasting, it also depends upon the data collection technique from ground-based field visits that constituted sample surveys based on crop harvesting 
experiments. These yield surveys are extensive as plot yield data are collected through stratified multistage random sample techniques. From the data obtained in this way yields can be forecasted at the regional and national level [13]. However, such a technique has three major drawbacks: (i) it is time-consuming, subjective, and prone to significant discrepancies as a result of insufficient ground observations that cause poor crop production assessment $[11,12]$; (ii) the outcomes are usually made available to the government and public after several months of the harvesting of the crop, and thus not useful for food security purposes [14]; and (iii) it is costly, depending on the survey areas, e.g., a quarterly field survey for the entire Philippines required about CAD\$50,000 [15]. Currently, the ground-based data collection method is in practice in various countries across the world and some of the responsible organizations include National Bureau of Statistics of China, Central Statistical Office of India, and Bangladesh Bureau of Statistics. These organizations collect data at the basic administrative level/unit and then aggregate at the district, region and country-levels [16-18].

In this context, remote sensing-based methods have already been proven as an effective alternative for mapping rice area [19-33] and forecasting rice production [14,15,34-37]. The benefits of remote sensing technology include: (i) spatial coverage over a large geographic area; (ii) availability during all seasons; (iii) relatively low cost, since some optical images are freely available (i.e., MODIS, Landsat); although radar data are usually a bit costly (e.g., CAD $\$ 4000$ per scene); (iv) efficient analysis; (v) they provide information in a timely manner; and (vi) they are capable of delineating detailed spatial distributions of areas under rice cultivation. In addition, remote sensing-based methods for forecasting rice production may help the governments, planners, and decision makers to formulate appropriate policies to: (i) quantify either how much to import in the event of shortfall or optionally to export in case of a surplus [14]; and (ii) purchase rice sooner at a relatively cheaper price as other rice producing countries do not have information about this upcoming need. For these methods, either optical remote sensing-based surface reflectance or microwave remote sensing-based backscattering is usually used in both mapping and forecasting processes. One of the most important issues is that regardless the employed method (i.e., ground or remote sensing-based) the user requires fast, reliable (accurate), less costly, and least labour-intensive ways; and also forecasting should take place prior to harvesting of the crop.

In this paper, our objective was to provide an overview of the use of remote sensing imagery for mapping rice crop areas and forecasting its production. The specific goals were to review three major issues, such as: (i) suitable remote sensing-based methods for mapping rice areas and their limitations; (ii) remote sensing-based methods for forecasting rice yield and their functional implications; and (iii) the synergy between remote sensing-based methods and other developments for mapping rice area and forecasting its yield. In case of mapping rice areas, remote sensing images acquired over either entire growing season or some of the critical stages (e.g., transplantation, tillering, heading/booting, flowering, etc.) were used, as shown in Figure 1. On the other hand, the images acquired during the peak/maximum greenness stage (see Figure 1) were commonly used in the event of forecasting rice yield. Figure 1 also shows that a remotely sensed vegetation index of normalized difference vegetation index (NDVI) would:

(i) be low at the transplantation stage; (ii) increase over the vegetative-to-reproductive stage; and (iii) gradually decrease with the progression of the ripening stage. 


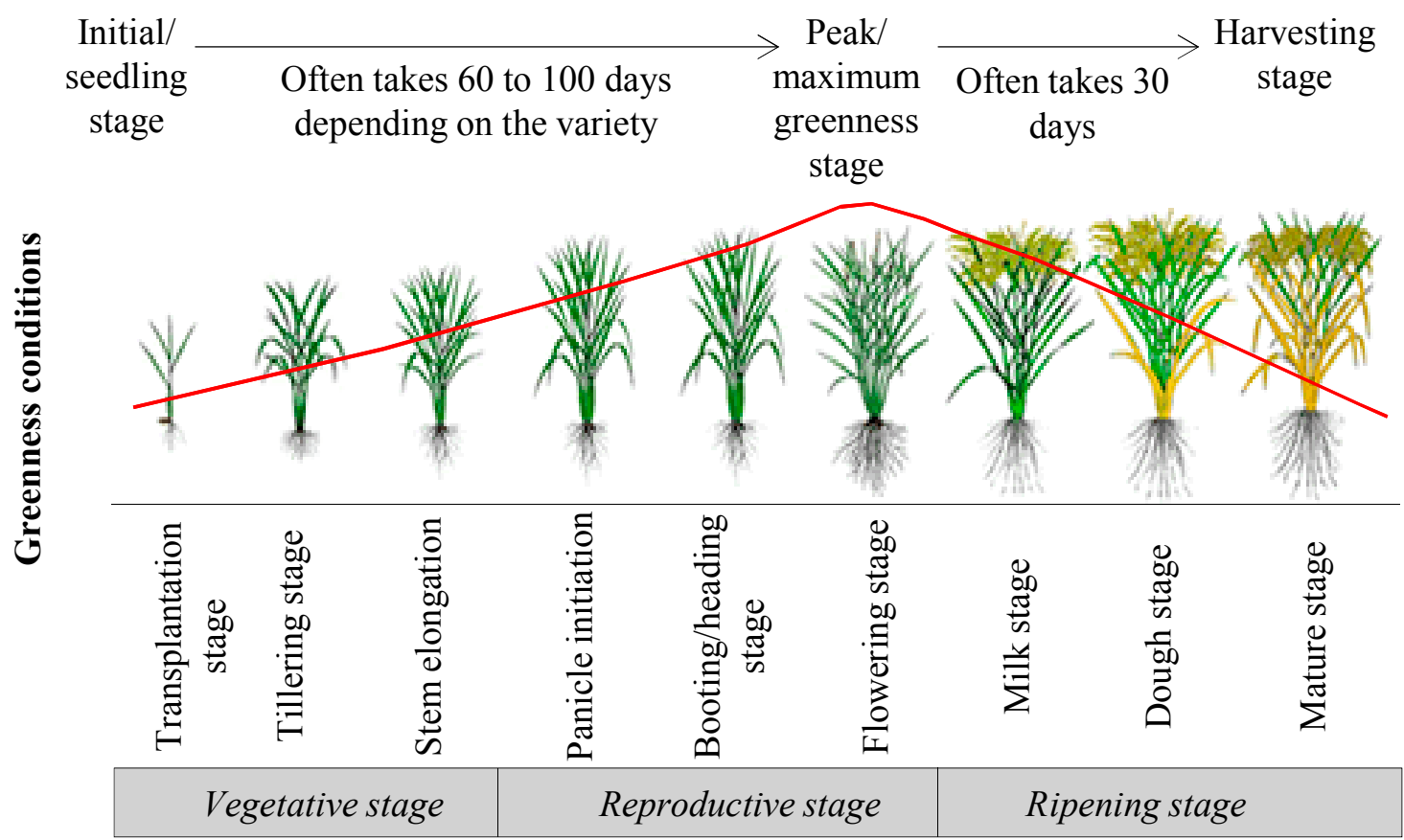

Growing stages

Figure 1. Growing stage of a typical rice crop and their associated greenness conditions (modified after [38]). The red curve shows a typical temporal dynamics of very commonly used remote sensing-based vegetation greenness index [i.e., normalized difference vegetation index (NDVI)].

\section{Remote Sensing-Based Methods for Mapping Rice Area}

Due to the ability of viewing the Earth's surface by the remote sensing platforms in a repetitive manner, several remote sensing-based methods were developed for mapping the rice areas in different parts of the World. Both optical and microwave remote sensing systems offer practical means for mapping rice areas which are described in the following sub-sections.

\subsection{Optical Remote Sensing-Based Mapping Methods}

Optical remote sensing sensors were widely used for mapping rice areas worldwide [19-33]. It was used in discriminating land use/land cover and measuring crop areas due to their ability to view the Earth surface in the spectral range 0.4 to $2.5 \mu \mathrm{m}$. The most commonly applied optical sensors include: Landsat (mainly MSS, TM and ETM+), SPOT-VGT, NOAA/AVHRR, MODIS, etc. These satellite sensors have the potential of obtaining multi-temporal and multi-spectral reflectance data over croplands that can be used for deriving time-series of vegetation indices (VIs), calculated as a function of red, blue, and infrared spectral bands (see the major VIs in Table 1). A number of studies have explored the usefulness of optical remote sensing sensors to identify rice areas; and some of the example cases are briefly described in Table 2. 
Table 1. List of the common vegetation indices, and their mathematical formula, which have been used in mapping and yield/production forecasting.

\begin{tabular}{|c|c|c|c|}
\hline Index & Abbreviation & Formula & Reference \\
\hline $\begin{array}{l}\text { Normalized } \\
\text { Difference } \\
\text { Vegetation Index }\end{array}$ & NDVI & $\frac{\rho_{N I R}-\rho_{R}}{\rho_{N I R}+\rho_{R}}$ & [39] \\
\hline $\begin{array}{l}\text { Ratio Vegetation } \\
\text { Index }\end{array}$ & RVI & $\frac{\rho_{N I R}}{\rho_{R}}$ & [40] \\
\hline $\begin{array}{l}\text { Enhanced Vegetation } \\
\text { Index }\end{array}$ & EVI & $2.5 \times \frac{\rho_{N I R}-\rho_{R}}{\rho_{N I R}+6 \times \rho_{R}+7.5 \times \rho_{B}+1}$ & [41] \\
\hline $\begin{array}{c}\text { Soil-Adjusted } \\
\text { Vegetation Index }\end{array}$ & SAVI & $\frac{\rho_{N I R}-\rho_{R}}{\rho_{N I R}+\rho_{R}+L}(1+L)$ & [42] \\
\hline $\begin{array}{l}\text { Land Surface Water } \\
\text { Index }\end{array}$ & LSWI* & $\frac{\rho_{\text {NIR }}-\rho_{\text {SWIRI }}}{\rho_{\text {NIR }}+\rho_{\text {SWIRI }}}$ & [22] \\
\hline $\begin{array}{c}\text { Normalized } \\
\text { Difference Built-up } \\
\text { Index } \\
\end{array}$ & NDBI & $\frac{\rho_{\text {SWIR1 }}-\rho_{\text {NIR }}}{\rho_{\text {SWIR1 }}+\rho_{\text {NIR }}}$ & [43] \\
\hline $\begin{array}{c}\text { Triangular } \\
\text { Vegetation Index }\end{array}$ & TVI & $\sqrt{\frac{\rho_{N I R}-\rho_{R}}{\rho_{N I R}+\rho_{R}}}+0.5$ & [44] \\
\hline $\begin{array}{c}\text { Difference } \\
\text { Vegetation Index }\end{array}$ & DVI & $\rho_{N I R}-\rho_{R}$ & [45] \\
\hline $\begin{array}{l}\text { Infrared Percentage } \\
\text { Vegetation Index }\end{array}$ & IPVI & $\frac{\rho_{N I R}}{\rho_{N I R}+\rho_{R}}$ & [46] \\
\hline $\begin{array}{c}\text { Perpendicular } \\
\text { Vegetation Index }\end{array}$ & PVI & $\frac{\rho_{N I R}-\mathrm{a} \times \rho_{R}-\mathrm{b}}{\sqrt{1+a^{2}}}$ & [47] \\
\hline $\begin{array}{c}\text { Rice Growth } \\
\text { Vegetation Index }\end{array}$ & RGVI & $1-\frac{\rho_{B}-\rho_{R}}{\left(\rho_{\text {NIR }}+\rho_{\text {SWIRI }}+\rho_{\text {SWIR2 }}\right)}$ & [28] \\
\hline
\end{tabular}

Note: $\rho$ is the surface reflectance values for blue (B), red (R), near infrared (NIR), Shortwave infrared (SWIR1 and SWIR2 are centered at $\sim 1.64$ and $2.22 \mu \mathrm{m}$ respectively); $L=0.5$; a (gain) and $\mathrm{b}$ (offset) are derived from NIR vs. RED scatter plot. * In fact, Gao [48] developed the LSWI first, however the name was normalized difference water index (NDWI) using SWIR1 centered at $1.24 \mu \mathrm{m}$. 
Table 2. Examples of optical remote sensing-based methods used for rice area mapping, which were usually evaluated against the agricultural statistical dataset unless stated differently.

\begin{tabular}{|c|c|c|}
\hline Sensor & Method & Outcomes \\
\hline Landsat MSS & $\begin{array}{l}\text { Evaluated two classification schemas using four images } \\
\text { (comprised of G, R, and two NIR spectral bands) acquired } \\
\text { during the transplantation to canopy development stages. } \\
\text { The first one was the use of maximum likelihood classifier } \\
\text { for generating the rice maps. The second one was the use } \\
\text { of a vector classifier using two nodes (i.e., water and green } \\
\text { canopy response). }\end{array}$ & $\begin{array}{l}\text { Between the two schemas, the vector } \\
\text { classifier was found to have better } \\
\text { agreements (i.e., } 94 \% \text { ) during the } \\
\text { calibration phase (i.e., during 1983/84 } \\
\text { season) over New South Wales, } \\
\text { Australia. It was then applied during } \\
\text { 1984/85 season and found similar } \\
\text { agreements (i.e., } \sim 95 \% \text { ) [49]. }\end{array}$ \\
\hline FORMOSAT-2 & $\begin{array}{l}\text { Used two images consisting of R, G, B, and NIR bands } \\
\text { acquired during transplanting and tillering stages. Two } \\
\text { classifiers were used: (i) geographic information system (GIS) } \\
\text { object-based post classification (GOBPC); and } \\
\text { (ii) pixel-based hybrid classification (i.e., both unsupervised } \\
\text { and supervised). }\end{array}$ & $\begin{array}{l}\text { GOBPC was found superior than the } \\
\text { pixel-based approach. The accuracy of } \\
\text { rice mapping was found to be more } \\
\text { than } 94 \% \text { over Yilan, Hualien, and } \\
\text { Kaohsiung; and } 82 \% \text { in Yunlin, } \\
\text { Taiwan [50]. }\end{array}$ \\
\hline \multirow[b]{2}{*}{ Landsat TM } & $\begin{array}{l}\text { Employed one image comprising of R, G, and B bands } \\
\text { acquired during the early growing season. Unsupervised } \\
\text { classifier was used under two conditions: (i) cut the study area } \\
\text { first then classify; and (ii) classify the entire image then cut the } \\
\text { study area. }\end{array}$ & $\begin{array}{l}\text { Between the two conditions, the later } \\
\text { condition (classify and cut) } \\
\text { demonstrated better accuracies of } \\
\sim 81 \% \text { for semi-late rice and } 90 \% \text { for } \\
\text { early rice crop over Hubei, China [51]. }\end{array}$ \\
\hline & $\begin{array}{l}\text { Carried out three procedures: (i) land use map and town } \\
\text { boundaries were created; (ii) optimal combination of three } \\
\text { bands (i.e., B, NIR, and SWIR1) were selected based on } \\
\text { optimum index factor using one image acquired during the } \\
\text { booting stage; and (iii) then ISODATA, parallelepiped, and } \\
\text { maximum likelihood classifiers were applied. }\end{array}$ & $\begin{array}{l}\text { Parallelepiped classifier was found the } \\
\text { best (i.e., an accuracy of } 82.85 \% \text { ) } \\
\text { among all the employed classifiers } \\
\text { over Longyou County, China [52]. }\end{array}$ \\
\hline \multirow[t]{2}{*}{ Landsat ETM+ } & $\begin{array}{l}\text { Implemented two masks: (i) desert area outside the irrigation } \\
\text { boundary using an irrigation schema map; and (ii) cloudy area } \\
\text { using supervised classifier of B, and thermal bands. They } \\
\text { employed supervised classifier over two scenes (i.e., one } \\
\text { during the growing stage and the other during the harvesting } \\
\text { stage) comprising of all spectral bands (except the thermal one) } \\
\text { individually. They also fused the optical bands of the both } \\
\text { scenes and then applied supervised classifier. }\end{array}$ & $\begin{array}{l}\text { Observed better outcomes (i.e., an } \\
\text { accuracy of } 98 \% \text { ) in case of using the } \\
\text { fused images over Mali, } \\
\text { West Africa [53]. }\end{array}$ \\
\hline & $\begin{array}{l}\text { Used six images spanning from the plantation to the harvesting } \\
\text { period. They evaluated relations between rice age and several } \\
\text { vegetation indices such as NDVI, RVI, IPVI, DVI, TVI, } \\
\text { SAVI and RGVI. Note that they introduced the concept of } \\
\text { using RGVI. }\end{array}$ & $\begin{array}{l}\text { Observed the best relation (i.e., } r^{2} \text { of } \\
0.90 \text { ) existed between the rice age and } \\
\text { RGVI during the calibration phase. The } \\
\text { application of the model showed } \\
\text { significant relations (i.e., } r^{2} \text { of } 0.97 \text { ) } \\
\text { over Bali, Indonesia [28]. }\end{array}$ \\
\hline $\begin{array}{l}\text { Huan Jing } \\
(\mathrm{HJ}-1 \mathrm{~A} / \mathrm{B})\end{array}$ & $\begin{array}{l}\text { Deployed twenty seven images comprised of B, G, R, and NIR } \\
\text { bands during the growing season of three rice types, such as } \\
\text { early-, medium-, and late-season rice. In determining the pure } \\
\text { rice pixels, they used support vector machine classifier. In } \\
\text { addition, they used "rice area fraction index" in identifying the } \\
\text { mixed pixels (i.e., mix of rice with other crops). }\end{array}$ & $\begin{array}{l}\text { Validated against Rapid Eye-derived } \\
\text { rice maps and found accuracies of } \\
99 \%, 99 \% \text {, and } 97 \% \text { for early-, } \\
\text { medium-, late-season rice, respectively } \\
\text { over Hunan, China [54]. }\end{array}$ \\
\hline $\begin{array}{l}\text { NOAA } \\
\text { AVHRR }\end{array}$ & $\begin{array}{l}\text { Employed NDVI images, i.e., one image during the peak } \\
\text { greenness stage in 1989; and four images during the vegetative } \\
\text { to peak greenness stage in 1999. In both of the years, they } \\
\text { implemented a density slicing approach for the area estimation. }\end{array}$ & $\begin{array}{l}\text { Found over estimations, i.e., } \sim 23.3 \text { and } \\
27.5 \% \text { in } 1989 \text { and } 1999 \text { respectively } \\
\text { for boro rice acreage over } \\
\text { Bangladesh [55]. }\end{array}$ \\
\hline
\end{tabular}


Table 2. Cont.

\begin{tabular}{|c|c|c|}
\hline Sensor & Method & Outcomes \\
\hline SPOT XS & $\begin{array}{l}\text { Used three images comprising of G, R and NIR bands during } \\
\text { the pre-flood and first half of the flood period (i.e., the earlier } \\
\text { stages of the rice season). They evaluated two classification } \\
\text { approaches. The first one was the integration of supervised and } \\
\text { unsupervised classification of a database formed by the } \\
\text { principal component reduction. The second one was } \\
\text { implementation of a series of steps, such as unsupervised } \\
\text { classification, stratification, and supervised classification. }\end{array}$ & $\begin{array}{l}\text { The second approach provided better } \\
\text { accuracy (i.e., } 70 \% \text { ) over Niger Delta, } \\
\text { Mali, West Africa [56]. }\end{array}$ \\
\hline SPOT VGT & $\begin{array}{l}\text { Developed a "peak detector algorithm" to differentiate } \\
\text { between rain-fed and irrigated rice crops. The 10-day } \\
\text { composite NDVI images over three calendar years were used } \\
\text { to determine cropping intensity (i.e., number, timing, and peak } \\
\text { values). Then the peak NDVI-values were lag-correlated with } \\
\text { the long-term average rainfall regimes. They found a "single" } \\
\text { peak NDVI for rain-fed rice; and "multiple" peak for the } \\
\text { irrigated rice. }\end{array}$ & $\begin{array}{l}\text { Found overall accuracy of } 89 \% \text { over } \\
\text { Suphanburi, Thailand [57]. }\end{array}$ \\
\hline \multirow{3}{*}{ MODIS } & $\begin{array}{l}\text { Used forty six 8-day composite of three vegetation/wetness } \\
\text { indices (that included LSWI, NDVI, and EVI) over the entire } \\
\text { calendar year. The LSWI was in particular used to identify the } \\
\text { initial period of flooding and transplantation of the rice; while } \\
\text { NDVI and EVI was used for understanding greenness } \\
\text { conditions of the crop. }\end{array}$ & $\begin{array}{l}\text { Observed reasonable agreement }\left(\text { i.e., } r^{2}\right. \\
\text { values ranging from } 0.80-0.88) \text { with } \\
\text { Landsat ETM+ derived rice maps over } \\
\text { Southern China [22]. }\end{array}$ \\
\hline & $\begin{array}{l}\text { Employed ten 16-day composite of NDVI images over the } \\
\text { entire growing season. The methods consisted of three steps, } \\
\text { i.e., (i) determining rice signatures using ISODATA clustering } \\
\text { techniques; (ii) formulating a mathematical model for } \\
\text { extracting rice areas on the basis of the signatures determined } \\
\text { in the first step; and (iii) model calibration and its validation. }\end{array}$ & $\begin{array}{l}\text { Observed reasonable agreements }(i . e ., \\
\text { percentage error in the range }-0.83 \text { to } \\
1.42 \% \text { at country-level; and } r^{2} \text { in the } \\
\text { range } 0.69 \%-0.89 \% \text { at district levels) } \\
\text { over Bangladesh [ } 58] \text {; and an example } \\
\text { boro rice acreage map of } 2010 \text { season } \\
\text { is shown in Figure } 2 \text {. }\end{array}$ \\
\hline & $\begin{array}{l}\text { Generated a potential rice cultivation area by digitizing a } \\
\text { hardcopy land use map, and then used to mask two NDVI } \\
\text { images acquired during early and late stage of rice plantation. } \\
\text { Finally, maximum likelihood classifier was applied on the } \\
\text { combined image for extracting the rice area. }\end{array}$ & $\begin{array}{l}\text { Observed an overall accuracy of } 95.7 \% \\
\text { over Zhejiang, China [59]. }\end{array}$ \\
\hline \multirow[t]{2}{*}{ IRS LISS-III } & $\begin{array}{l}\text { Used two images per year comprising of G, R, and NIR } \\
\text { acquired during the early and vegetative stages of rice. The } \\
\text { employed methods consisted of: (i) maximum likelihood } \\
\text { classifier; (ii) establishing relationship between classified } \\
\text { image and GPS measured area; and (iii) estimation of the } \\
\text { rice area under hill shades and non-visible area based on } \\
\text { field survey. }\end{array}$ & $\begin{array}{l}\text { Found a good relationship between: } \\
\text { (i) classified image and GPS measured } \\
\text { area (i.e., } r^{2} \text { value of } 0.91 \text { ); and (ii) eye } \\
\text { estimates and actual measurement (i.e., } \\
r^{2} \text { value of } 0.95 \text { ) within the buffer zone } \\
\text { over Ri-Bhoi, Meghalaya, India [60]. }\end{array}$ \\
\hline & $\begin{array}{l}\text { Utilized: (i) digital elevation model to calculate the slope } \\
\text { classes and considered the classes between } 0 \%-25 \% \text { slopes; } \\
\text { (ii) multi-date LISS and land use maps to identify rice } \\
\text { cultivation areas; (iii) soil maps to extract suitable soils for rice } \\
\text { crop. Finally all of the layers were overlaid to generate } \\
\text { potential rice areas. }\end{array}$ & $\begin{array}{l}\text { The use of LISS improved the } \\
\text { assessment, i.e., an additional } \\
746.44 \mathrm{~km}^{2} \text { potential rice areas were } \\
\text { identified over Mizoram, India [61]. }\end{array}$ \\
\hline
\end{tabular}




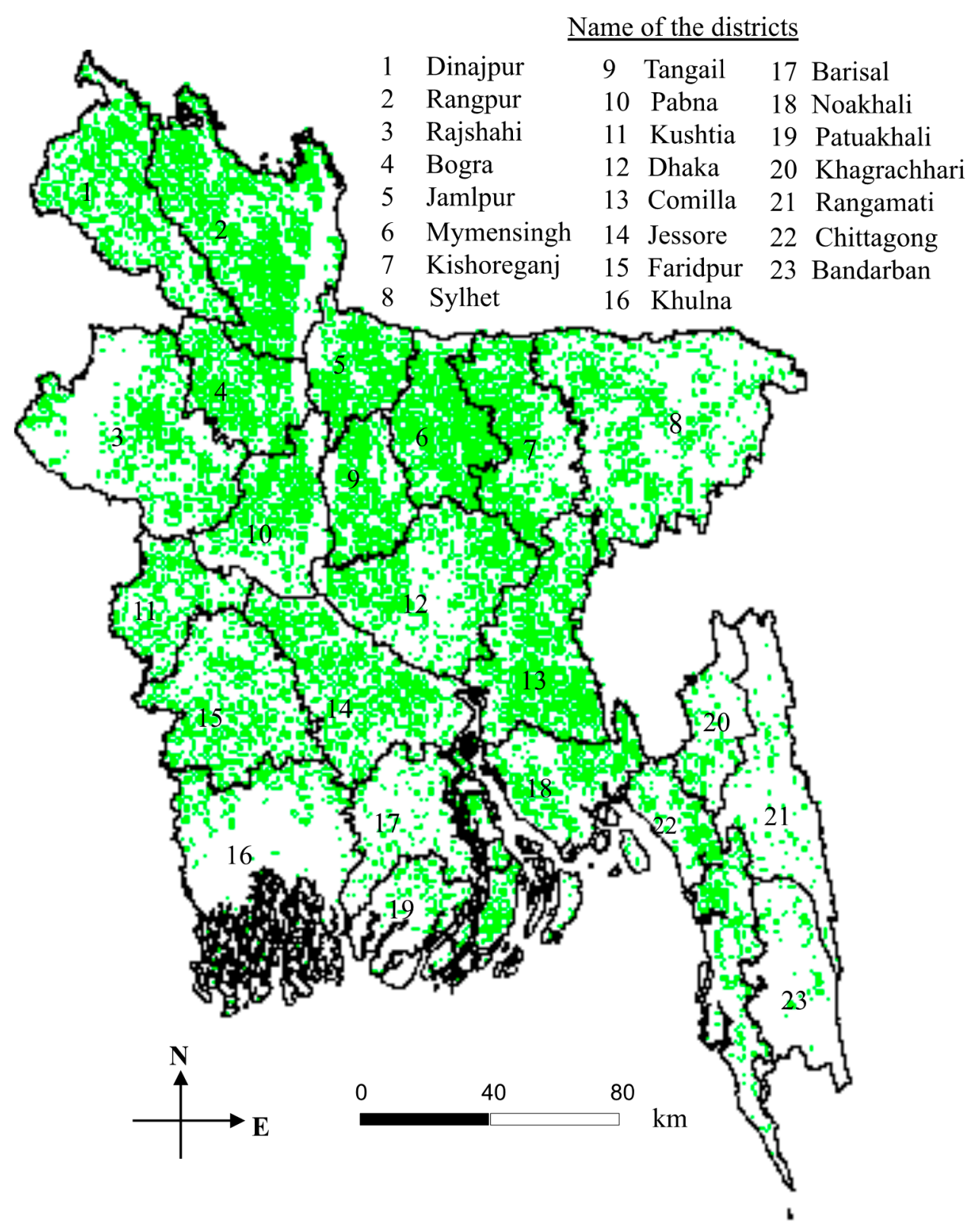

Figure 2. Example of MODIS-derived boro rice cultivation area (indicated using green shades) mapping during 2010.

\subsection{Microwave Remote Sensing-Based Mapping Methods}

One of the prime advantages of microwave remote sensing is associated with its ability of acquiring images theoretically under any weather conditions, such as cloud cover, rain, snow, and solar irradiance. Therefore, the radar images collected from microwave sensors provide an excellent imagery source for mapping rice areas, where rice cultivation takes place during rainy season with dominant cloudy conditions. Since the 1990s, researchers have explored the usefulness of microwave data retrieved from different satellites (e.g., ERS-1 and 2, RADARSAT-1 and 2, ENVISAT ASAR, etc.). In general, the temporal variation of radar backscatter over the growing season was the key factor in delineating rice areas; and some of the example studies are briefly described in Table 3. 
Table 3. Examples of microwave remote sensing-based methods used for rice area mapping, which were usually evaluated against the agricultural statistical dataset unless stated differently.

\begin{tabular}{|c|c|c|}
\hline Sensor & Method & Outcomes \\
\hline \multirow{2}{*}{$\begin{array}{l}\text { ERS-1 (C-band } \\
\text { with VV } \\
\text { polarization) }\end{array}$} & $\begin{array}{l}\text { Implemented maximum likelihood classifier using four } \\
\text { multi-temporal images acquired between } 25-30 \text { days of } \\
\text { transplantation to the initiation of flowering stage } \\
\text { (i.e., } 60-70 \text { days). }\end{array}$ & $\begin{array}{l}\text { Found accuracy of } 90 \text { and } 91.5 \% \\
\text { over Howrah and Hughly districts, } \\
\text { respectively in West Bengal, India [62]. }\end{array}$ \\
\hline & $\begin{array}{l}\text { Applied maximum likelihood classifier along with } \\
\text { principal component analysis over six multi-temporal } \\
\text { images acquired during the entire growing season. }\end{array}$ & $\begin{array}{l}\text { Obtained an accuracy of } 90 \% \text { in } \\
\text { comparison with the land use survey } \\
\text { and Landsat TM-derive maps over } \\
\text { Akita, Japan [63]. }\end{array}$ \\
\hline $\begin{array}{l}\text { ERS-2 (C-band } \\
\text { with VV } \\
\text { polarization) }\end{array}$ & $\begin{array}{l}\text { Generated five change index (CI) maps from seven images } \\
\text { acquired during the growing season. Then each pixel in } \\
\text { these CI maps was classified into one of three classes: } \\
\text { increasing, decreasing, or constant backscattering. }\end{array}$ & $\begin{array}{l}\text { Compared against SPOT-derived rice } \\
\text { maps and found } 93.2 \% \text { agreements over } \\
\text { Mekong River Delta, Vietnam [64]. }\end{array}$ \\
\hline \multirow[b]{3}{*}{$\begin{array}{l}\text { RADARSAT-1 } \\
\text { (C-band with HH }\end{array}$} & $\begin{array}{l}\text { Deployed three multi-temporal images for each of the } \\
\text { standard and fine beam modes acquired during } \\
\text { transplanting and reproductive stages. }\end{array}$ & $\begin{array}{l}\text { Found strong relation with an } \\
\text { accuracy of } 87 \% \text { when compared to } \\
\text { the available land cover map over } \\
\text { Java Island, Indonesia [65]. }\end{array}$ \\
\hline & $\begin{array}{l}\text { Applied a neural network classifier and post classification } \\
\text { filtering over three multi-temporal images acquired during } \\
\text { early growth/transplanting, flowering, and harvest stages. }\end{array}$ & $\begin{array}{l}\text { Observed accuracy of } 97 \% \text { over } \\
\text { Zhaoqing and Guangdong, } \\
\text { China [66]. }\end{array}$ \\
\hline & $\begin{array}{l}\text { Implemented a knowledge-based decision rule classifier } \\
\text { based on the temporal variations of SAR backscatter of all } \\
\text { land-cover classes using three multi-temporal images } \\
\text { acquired during transplanting, and vegetative stages. }\end{array}$ & $\begin{array}{l}\text { Noted an accuracy of }>98 \% \text { over } \\
\text { Baleshwar and Bhadrak districts, } \\
\text { Orissa, India [67]. }\end{array}$ \\
\hline
\end{tabular}

polarization) Used nine and ten multi-temporal images acquired during dry and wet seasons respectively. They carried out four classification approaches (i.e., neural network classification; maximum likelihood classification; change detection; and an integration of change detection and neural network).

Executed a combination of entropy decomposition and Revealed that the integrated method performed well with an accuracy of $>96 \%$ over Munoz and Santo Domingo, Philippine [68]. support vector machine methods using three multi-temporal images acquired during vegetative, reproductive/peak, and ripening stages.

Found an accuracy of $95.3 \%$ when compared to the maximum likelihood classifer-dervied maps over Sungai Burung, Selangor, Malaysia [69].

\section{ENVISAT} ASAR (C-band with $\mathrm{HH} / \mathrm{HV}$ polarizations)

\section{ENVISAT}

ASAR (C-band with VV and $\mathrm{HH}$ polarization)

\section{ALOS PALSAR}

(L-band with $\mathrm{HH}$ polarization)
Developed empirical relationships between backscattering coefficient, height, and biomass of rice using four multi-temporal $\mathrm{HH}$ and $\mathrm{HV}$ polarized images.

Implemented image difference technique using three pairs of images acquired during flooding, reproductive/peak, and ripening stages for each of the $\mathrm{VV}$ and $\mathrm{HH}$ polarization.

Applied support vector machine classifier based on the temporal variation of the backscatter using three multi-temporal images acquired during transplanting, vegetative, and heading stages.
Observed an accuracy of $81 \%$ over Southern China [70].

Found the best results from the difference image of $\mathrm{HH}$ polarization (i.e., producer's and user's accuracies were $94 \%$ and $87 \%$ respectively) over Fuzhou, China [71].

Obtained user's and producer's accuracies of $90 \%$ and $76 \%$ respectively over Zhejiang, southeast China [72]. 


\subsection{Integration of Optical and Microwave Remote Sensing-Based Mapping Methods}

In addition to the independent use of optical and microwave remote sensing-based methods, several studies have been conducted upon combining both of the methods together for mapping rice areas; and some of the example cases are briefly described in Table 4.

Table 4. Examples of integrating the optical and microwave imagery remote sensing data in mapping rice areas; which were usually evaluated against the agricultural statistical dataset unless stated differently.

\begin{tabular}{|c|c|c|}
\hline Sensor & Method & Outcomes \\
\hline $\begin{array}{l}\text { Landsat TM (visible and } \\
\text { shortwave infrared bands) } \\
\text { and JERS-1 SAR (L-band } \\
\text { with HH polarization) }\end{array}$ & $\begin{array}{l}\text { Applied unsupervised classification over } \\
\text { TM image to determine arable land area } \\
\text { during dry season; and used SAR data to } \\
\text { delineate rice areas during rainy season. }\end{array}$ & $\begin{array}{l}\text { Found the estimated rice areas } \\
\text { were } 12 \%-14 \% \text { smaller over } \\
\text { Indramayu, Indonesia [ } 73] .\end{array}$ \\
\hline $\begin{array}{l}\text { IRS-1D LISS-III (G, R, } \\
\text { and NIR bands) and } \\
\text { RADARSAT-1 SAR } \\
\text { (C-band with HH } \\
\text { polarization) }\end{array}$ & $\begin{array}{l}\text { Employed: (i) maximum likelihood } \\
\text { classifier using LISS-III data acquired } \\
\text { during dry and summer seasons to map } \\
\text { dry-to-summer rice; and (ii) temporal } \\
\text { analysis using SAR data to determine rainy } \\
\text { season rice map. The outcomes were } \\
\text { combined to produce map year-round rice. }\end{array}$ & $\begin{array}{l}\text { Noticed agreements of about } \\
96.6 \% \text { for the year-round rice } \\
\text { over West Bengal, India [74]. }\end{array}$ \\
\hline $\begin{array}{l}\text { Landsat TM (visible and } \\
\text { shortwave infrared bands) } \\
\text { and RADARSAT-1 SAR } \\
\text { (C-band with HH } \\
\text { polarization) }\end{array}$ & $\begin{array}{l}\text { Used three fusion algorithms (i.e., principal } \\
\text { component analysis, multiplicative, and } \\
\text { Brovey) to merge TM acquired during } \\
\text { growing period and three multi-temporal } \\
\text { radar images acquired during early, } \\
\text { vegetative, harvesting stages; and then } \\
\text { applied three classification schemas (i.e., } \\
\text { maximum likelihood, Mahalanobis } \\
\text { distance, and minimum to mean distance). }\end{array}$ & $\begin{array}{l}\text { Observed that the Mahalanobis } \\
\text { distance over the Brovey fused } \\
\text { image provided the best results } \\
\text { (i.e., } 87.41 \% \text { ) in comparison to } \\
\text { the rice maps, that was produced } \\
\text { through extensive ground truthing } \\
\text { and TM images acquired earlier } \\
\text { than the ones used in this study } \\
\text { over Mazandarm, Iran [75]. }\end{array}$ \\
\hline $\begin{array}{l}\text { Visible-to-shortwave } \\
\text { infrared bands of MODIS } \\
\text { and Landsat } 7 \text { ETM+; and } \\
\text { ALOS PALSAR (L-band } \\
\text { with HH polarization) }\end{array}$ & $\begin{array}{l}\text { Employed both of the multi-temporal } \\
\text { PALSAR and MODIS images to define rice } \\
\text { phenology and inundation patterns; and } \\
\text { then a single ETM+ image to characterise } \\
\text { "lake/water bodies masking". }\end{array}$ & $\begin{array}{l}\text { Revealed a high overall accuracy } \\
\text { of } 89 \% \text { over Poyang lake } \\
\text { Watershed, China [76]. }\end{array}$ \\
\hline $\begin{array}{l}\text { AWiFS (G, R, NIR, and } \\
\text { SWIR1 bands) and } \\
\text { RADARSAT-1 SAR } \\
\text { (C-band with HH } \\
\text { polarization) }\end{array}$ & $\begin{array}{l}\text { Implemented hierarchical decision rule } \\
\text { classification technique using: (i) two SAR } \\
\text { images acquired during transplanting } \\
\text { period; and (ii) AWiFS-derived NDVI, } \\
\text { SWIR1/R and NIR/G ratios during the peak } \\
\text { greenness stage. }\end{array}$ & $\begin{array}{l}\text { Noticed that the deviation in } \\
\text { the area calculated was } 1.93 \text { and } \\
-10.5 \% \text { over Bargarh and } \\
\text { Sonepur districts respectively in } \\
\text { Orissa, India [77]. }\end{array}$ \\
\hline
\end{tabular}

\subsection{Limitations of Remote Sensing-Based Mapping Methods}

For most of the optical remote sensing-based methods, the spatial resolution of the employed images (i.e., MODIS, AVHRR, and SPOT-VGT) were relatively low (i.e., in the range $500 \mathrm{~m}$ to $1.1 \mathrm{~km}$ ). This 
particular issue would be critical as the dimension of some rice fields might be smaller than the spatial resolution of these satellite platforms. In the context of spatial resolution, the use of Landsat imagery would compensate the spatial resolution; however, sometimes it would be very difficult to obtain cloud-free images over some of the rice growing regions of the World. Also, temporal resolution (i.e., 16 days) of the Landsat images and its swath coverage (i.e., approximately $180 \mathrm{~km}$ ) might restrict their application in rice mapping. These impose a problem for rice mapping especially when the period of interest falls in rainy season and during which heavy cloud greatly influences the image quality $[21-23,58,78]$. Another factor, such as variable topography would significantly impact the delineation of the rice areas as the surface reflectance from the hill terrain might be influenced by the adjacent areas $[22,23,50,55]$. In general, the microwave remote sensing platforms usually provide relatively higher spatial resolution images; however, several limitations exist, such as:

(i) It has an inherent problem of speckles, which look as a grainy "salt and pepper" texture in the image. These are formed due to random constructive and destructive interference from the multiple scattering returns that occur within each pixel/cell. These speckles degrade the quality of an image and make the interpretation process (visual or digital) more difficult [79].

(ii) The brightness of the radar backscatters are highly influenced by several factors, such as, volume scattering over vegetation, surface moisture conditions, surface roughness, local incidence angle, surface cover density, surface scattering properties, structure of the scattering surface, dielectric constant of the scattering material, and double bouncing from the right angle surface [80].

(iii) Geometric distortions, such as foreshortening, layover, and shadowing, exist in almost all radar imagery. For example, radar shadow occurs when the radar beam is not able to illuminate the ground surface [81]. Thus, all these factors have its influence during mapping rice cultivated areas, particularly in regions with steep topography and rough terrain.

(iv) Most of the studies of mapping rice area are based on single polarized image, where similar backscattering can occur from different land cover types. Hence, the multi-temporal dual polarization SAR imagery could be a promising source for rice mapping particularly in highly fragmented agricultural lands [66,82]. For example, Inou et al. [83] used a multifrequency (Ka, $\mathrm{Ku}, \mathrm{X}, \mathrm{C}$ and $\mathrm{L})$ polarimetric $(\mathrm{HH}, \mathrm{VH}, \mathrm{HV}$, and $\mathrm{VV})$ scatterometer with four incident angles $\left(25^{\circ}, 35^{\circ}, 45^{\circ}\right.$ and $\left.55^{\circ}\right)$ for the entire rice crop period, i.e., before transplantation until postharvest cultivation in understanding the relation between backscattering and rice-related growth variables over Tsukuba, Japan. However, conducting a similar study like Inou et al. [83] would be quite expensive.

(v) Mapping rice area at large scale using radar data is costly, where the high cost of using continuous radar imagery making it inappropriate for seasonal rice crop monitoring and mapping.

\section{Remote Sensing-Based Methods for Forecasting Rice Yield/Production}

\subsection{Optical Remote Sensing-Based Forecasting Methods}

Researchers have dedicated significant efforts to forecasting rice yield using optical remote sensing images. The pre-harvest yield estimation could be possible as some of the spectral bands of the optical remote sensing satellites would be responsive to the vegetation conditions. For example, vegetation 
absorbs energy in the spectral range $0.45-0.70 \mu \mathrm{m}$, and reflects in the range $0.70-0.90 \mu \mathrm{m}$. By use of these spectral ranges, several vegetation indices have been employed, such as NDVI, RVI, DVI, IPVI, SAVI, vegetation condition index (VCI), vegetation health index (VHI), temperature condition index (TCI), and green normalized difference vegetation index (GNDVI) to estimate yield before harvesting and their applications are described in Table 5.

Table 5. Examples of optical remote sensing-based methods used for forecasting rice yield/production.

\begin{tabular}{|c|c|c|}
\hline Sensor & Method & Outcomes \\
\hline $\begin{array}{l}\text { IRS } \\
\text { LISS-1A }\end{array}$ & $\begin{array}{l}\text { Used the ratio between NIR and R spectral } \\
\text { bands derived from IRS LISS images in order } \\
\text { to develop an empirical relationship with } \\
\text { ground-based yield data. }\end{array}$ & $\begin{array}{l}\text { Found the deviation of the estimated yield varied } \\
\text { from } 2 \% \text { to } 14 \% \text {, with } r^{2} \text { of } 0.52 \text { and RMSE of } 2.62 \\
\text { at the district level over Cuttack and Puri of Orissa, } \\
\text { India [84]. }\end{array}$ \\
\hline \multirow[b]{2}{*}{ MODIS } & $\begin{array}{l}\text { Used 8-day composite of NDVI values to } \\
\text { determine } \text { NDVI }_{\max } \text { at around } 45-60 \text { days } \\
\text { since the plantation; and compared with the } \\
\text { actual yield data. }\end{array}$ & $\begin{array}{l}\text { Revealed strong relationship, i.e., } r^{2} \text { of } 0.89 \text { over } \\
\text { Tabanan Regency, Bali province, Indonesia [85]. }\end{array}$ \\
\hline & $\begin{array}{l}\text { Utilized 8-day composite of EVI and leaf } \\
\text { area index (LAI) during the heading stages. } \\
\text { Eight models (i.e., derived from linear, } \\
\text { interaction, quadratic, and pure quadratic) of } \\
\text { rice crop yield, EVI and LAI were developed. }\end{array}$ & $\begin{array}{l}\text { Observed that the quadratic model based on EVI } \\
\text { and LAI produced the best results during the } \\
\text { ripening period for the spring-winter and } \\
\text { autumn-summer rice crop, that is, } r^{2} \text { of } 0.70 \text { and } \\
0.74 \text {, respectively over Mekong Delta, } \\
\text { Vietnam [86]. }\end{array}$ \\
\hline $\begin{array}{l}\text { Landsat } \\
\text { ETM+ }\end{array}$ & $\begin{array}{l}\text { Established relations between NDVI-values } \\
\text { at } 63 \text { days since the plantation and } \\
\text { ground-based yield observation. }\end{array}$ & $\begin{array}{l}\text { Found strong exponential relations }\left(i . e ., r^{2} \approx 0.85\right) \\
\text { with rice yield during model development phase. } \\
\text { The application of the model revealed strong } \\
\left.\text { relations (i.e., } r^{2} \approx 0.93\right) \text { between ground-based } \\
\text { estimate and the forecasted rice yield over Bali, } \\
\text { Indonesia [87]. }\end{array}$ \\
\hline $\begin{array}{l}\text { NOAA } \\
\text { AVHRR }\end{array}$ & $\begin{array}{l}\text { Used 7-day composite of NDVI and } \\
\text { brightness temperature-values at } 16 \mathrm{~km} \\
\text { resolution to calculate a set of vegetation } \\
\text { health indices (i.e., VCI, TCI, and VHI) in } \\
\text { order to forecast yield for Aus and Aman. }\end{array}$ & $\begin{array}{l}\text { For the Aus, both of indices VCI and VHI-values } \\
\text { between the plantation and early growing season } \\
\text { had similar relationship (i.e., } r^{2} \approx 0.62 \text { ) with the } \\
\text { yield. In addition, comparison of ground-based and } \\
\text { predicted rice yield was found to have } r^{2} \text { of } 0.56 \text {. On } \\
\text { the other hand, combination of VCI and TCI during } \\
\text { the period of reproductive phase (i.e., one/two } \\
\text { months prior to harvesting) had strong relations } \\
\text { (i.e., } r^{2} \approx 0.97 \text { ) for Aman yield. Also, the } \\
\text { relationship between ground-based and predicted } \\
\text { rice yield was found strong (i.e., } r^{2} \geq 0.89 \text { ) over } \\
\text { Bangladesh [34,35]. }\end{array}$ \\
\hline SPOT-4 & $\begin{array}{l}\text { Employed various reflective spectral bands } \\
\text { and their derivatives in the form of several } \\
\text { vegetation indices (i.e., red, near infrared, } \\
\text { and vegetation indices of DVI, IPVI, RVI, } \\
\text { NDVI and SAVI). }\end{array}$ & $\begin{array}{l}\text { Showed strong relations (i.e., } r^{2} \text { in between } 0.75 \text { to } \\
0.89 \text { ) with the yield at } 90 \text { days from sowing (i.e., } \\
\text { maximum vegetation growth stage). Further } \\
\text { comparison between actual and predicted rice yield } \\
\text { showed high correlation (i.e., } r^{2} \text { in between } 0.90 \text { to } \\
\text { 0.95) over Kafr El-Sheikh Governorate, Egypt [14]. }\end{array}$ \\
\hline
\end{tabular}




\subsection{Microwave Remote Sensing-Based Forecasting Methods}

Several studies have been conducted since 1990's for rice crop forecasting using microwave imagery and demonstrated encouraging results. Some relevant studies are described as follows:

- Shao et al. [66] used three RADARSAT-1 (C-band with HH polarization) images at different stages (i.e., the end of the seedling period, flowering period, and beginning of the harvesting period) for rice yield estimation over Zhaoqing in Guangdong Province, Southern China. The temporal dynamics of the backscatter-values were investigated and found an accuracy of $91 \%$ compared with actual yield.

- Li et al. [88] used three RADARSAT-1 (C-band with HH polarization) images acquired during early, middle, and prior-to-harvesting stages for rice yield estimation over Guangdong Province, Southern China. A multi-regression model was developed between backscatter coefficients and yield (i.e., rice biomass); and found a strong relation (i.e., $r^{2} \approx 0.91$ ) with actual yield.

- Chen and McNairn [68] utilized RADARSAT-1 (C-band with HH polarization) for rice forecasting over Munoz and Santo Domingo, Philippine. They applied a neural network-based model to predict rice yield using the relationship between rice growth and radar backscatter; and found an encouraging prediction accuracy of $94 \%$ in comparison to actual yield.

\subsection{Limitations of Remote Sensing-Based Forecasting Methods}

It would be interesting to note that the limitations we discussed regarding the remote sensing-based methods for rice mapping (see Section 2.4) would also applicable for forecasting rice yield. In addition, the following factors would also be critical:

- All of the methods described above (i.e., see Sections 3.1 and 3.2) were empirical in nature so that further calibration and validation would be required prior to implementing over other geographical locations. Technologically, empirical models were found to be relatively simple to build or develop, but these models could not take account of temporal changes in crop yields without long-term field experiments [89].

- These methods didn't describe the mechanism of delineating the rice acreage. Thus it might be possible to observe misclassification in case of mixing crop types [90].

- These methods were based on empirical/statistical models that needed to be performed on continuing basis and for different agro-climatic zones (i.e., due to changing environmental conditions and weather shifts at different locations) [14,36].

- In general, a specific value of either optical remote sensing-based indices or microwave remote sensing-based backscattering coefficients might represent variable yield. This would be due to: (i) genetic variations; (ii) climatic conditions; (iii) soil types; and (iv) intra-species competitions. For example, Boro rice (which grows in winter) in Bangladesh demonstrated yields in the range of 1.93 to 4.69 metric ton per hectare during 2012 [91]. 


\section{Synergy between Remote Sensing-Based Methods and Other Ones}

Upon reviewing the existing literature, we found that the synergy between remote sensing and other methods could broadly be classified into two categories: synergy between remote sensing-based methods and (i) meteorological parameters; and (ii) crop growth models. These categories are briefly discussed in the following sub-sections.

\subsection{Synergy between Remote Sensing-Based Methods and Meteorological Parameters}

This approach is based on the integration of meteorological parameters with remote sensing-based methods for forecasting rice yield/production; and some example cases are summarized as follows:

- Prasad et al. [89] used AVHRR-derived 10-day composite of NDVI images integrating with meteorological parameters (i.e., surface temperature, and rainfall) and soil moisture over India. A non-linear iterative multivariate optimization approach was used to derive an empirical piecewise linear crop yield prediction equation. The crop yield prediction model showed a high correlation coefficient that achieved accuracy greater than $90 \%$.

- Sarma et al. [92] examined the importance of meteorological variables, i.e., annual rainfall, southern oscillation index, sea surface temperature, growing degree day, combined with the AVHRR-derived NDVI in developing the statistical agro-climatic model in predicting the rice yield for kharif and rabi seasons over Andra Pradesh, India. The multi-regression model was employed; and found reasonable agreements between the actual and estimated rice yield (i.e., $r^{2} \sim 0.71$ ).

- Savin and Isaev [93] used a process-based model where the input variables included MODIS-derived 10-day composite of NDVI, fraction of absorbed radiation (fPAR), and meteorological variables (i.e., temperature, and incident solar radiation) over the Republic of Kalmykia. During the period of maximum plant greenness, the model outcomes were the best (i.e., always shown over prediction in the range $14 \%-48 \%$ in comparison to the actual yield).

\subsection{Synergy between Remote Sensing-Based Methods and Crop Growth Model}

The integration of remotely sensed data and rice crop growth models have become increasingly recognized as a potential tool for rice yield forecasting [94]. This approach relies on retrieval of biophysical crop parameters from remotely sensed data, which have been used as a direct input in rice crop models [95]. Various methods were found in the literature; some of such examples are as follows:

- Ribbes and Le Toan [96] used ERS-1 (C-band with VV polarization) and RADARSAT-1 (C-band with $\mathrm{HH}$ polarization) data to establish relationship between the backscattering coefficient and rice growth parameters, such as rice plant age, height, and biomass over Semarang and Jatisari, Indonesia. The sowing date and rice plant biomass values were determined from the relationships, and used as inputs in a rice crop growth model ORYZA1 (i.e., simulates crop growth under irrigated conditions with optimum supply of nutrients, and without pest and disease infestation [97]) to estimate the rice yield. Good agreements were found between the simulated and no stress yield [i.e., error below 15\% (around 1.5 ton/ha) using RADARSAT; and 9\% (around 0.7 ton/ha) using ERS data, respectively]. 
- Jing-Feng et al. (2002) [98] considered three types of AVHRR-derived NDVI-values, such as local area coverage (LAC)-NDVI, global area coverage (GAC)-NDVI, and radiometric measurements-NDVI; which were subsequently used as an input in the rice growth simulation model ORYZA1 [97] to develop a new model (called Rice-SAS model) to estimate rice yield for different growing seasons over Shaoxing province, China. The LAC-NDVI showed best estimates for rice yield with an estimation error of $1.03 \%, 0.79 \%$ and $-0.79 \%$ for early, single, and late season, respectively.

- Shen et al. [99] used multi-temporal and multi-polarized ENVISAT ASAR (C-band with HH/VV polarization) data acquired during vegetative, reproductive, and ripening stages integrated with rice crop model ORYZA2000 (i.e., simulates the growth and development of rice in situations of potential production, water, and nitrogen limitations [100]) for rice yield estimation over Xinghua, Jiangsu Province, China. The employed methods consisted of two steps: (i) generating a rice acreage map using ASAR dataset; and (ii) extracting the temporal dynamics of backscattering coefficients over the rice areas and assimilated with the ORYZA2000 model to predict rice yield. The obtained rice yield map was found to have over estimations by $13 \%$ on an average with a root mean square error of approximately $1133 \mathrm{~kg} / \mathrm{ha}$.

- Guo et al. [101] used multi-temporal MODIS data and HJ environment satellite-derived NDVI and EVI with LAI measurements integrated with rice production model ORYZA2000 [100] to estimate regional rice yield over Jiangsu Province, China. The obtained rice yield was found to have relative error of $6.31 \%$ compared with actual statistical data.

\subsection{Limitations of Synergy between Remote Sensing-Based Methods and Other Ones}

The synergy between remote sensing-based methods and other ones (i.e., meteorological parameters, and crop growth models) provided promising results in both mapping and forecasting of rice crop. However, they have several limitations, such as:

(i) Utilization of meteorological data has several implications that include: spatial distribution of meteorological stations (i.e., located sparsely in a large geographic landscape), incomplete and unavailable in a timely manner, and do not adequately represent the diversity over large areas $[102,103]$;

(ii) Forecasting of rice production in the vicinity of the meteorological stations might be more accurate compared to other parts of the landscape, if the meteorological parameter-based models would be properly calibrated and validated. However, it would not be possible to install more and more meteorological stations across the landscape due to the expenses related to the installation, maintenance, data collection, and its processing [104];

(iii) Long-term meteorological data are hard to find in most of the rice crop growing countries in the world [35], which are inadequate for reliable forecasting of rice production;

(iv) In generating the spatial dynamics for a meteorological variable of interest, GIS-based interpolation techniques are usually used, which can produce different map outputs using the same input datasets [105]. Therefore, forecasting of rice production thus limits the use of meteorological based information over large geographic extent; and 
(v) Crop growth models are found to be more complex and require many input parameters. These include: several biophysical parameters (e.g., soil and meteorological variables) and plant parameters (e.g., biomass, LAI, and height, age etc.); which are usually expensive, labour-intensive, time consuming in acquisition [106].

\section{Concluding Remarks}

Here, we have provided an overview of using remote sensing sensors and their limitations in mapping the rice crop area and forecasting its production. In terms of the mapping the rice areas, the optical remote sensing imagery has relatively low spatial resolution, which results in over- and underestimation of the area under cultivation. The SAR imagery has several limitations in mapping rice areas, such as the fact speckles degrade the quality of the images, brightness of the backscatters is highly sensitive to the interacting surface, geometric distortions (particularly in irregular topography), low classification accuracy due to use of single polarization, and costly mapping of large geographic areas. In addition, the temporal resolution of microwave imagery was relatively low (i.e., ranging between 24 to 44 days), which make it unfit for forecasting rice crop production prior to harvesting. Furthermore, the use of optical imagery in forecasting rice production was found to be encouraging, but mostly empirical-based. It is to be noted that most of the methods suffer from various aspects in particular how to implement them in other geographical locations i.e., not transferable/extendable due to climatic variability (i.e., temperature, precipitation amount, duration, and timing); soil characteristics (i.e., texture, moisture capacity, etc.); management practices (i.e., levee construction, fertilizer, irrigation, etc.); and selection of rice varieties (i.e., tolerance to submergence, drought, salinity, disease and insect). Climate change is also evident in many regions of the World (i.e., the average global temperature has increased by $0.74{ }^{\circ} \mathrm{C}$ in the last 100 years; rainfall has trended downward during 1960-2000 [107]) which will impact the rice crop productivity. Therefore, to assess and address the effect of climate change on the rice varieties (and its productivity), it is necessary to determine their genetic coefficients through carefully controlled experiments, trend of climate variation during the growth stages, and necessary to improve management practices to offset the adverse effects of climate change [108]. In addition, studies are required to evaluate the potential of applying multi-year remote sensing data for quantifying inter-annual variations of rice fields and its production due to extreme climate events (e.g., flooding, drought, cyclone, etc.) and/or human-driven land use changes. Also, factors such as plant diseases and insect infestation could be responsible for production losses, which could be monitored using remote sensing platforms [109]; however these were beyond the scope of this paper.

Despite the reasonable accuracies of rice area mapping and forecasting its production using remote sensing-based methods, such developments have many challenges as an operational one, which can be viewed as: (i) data acquisition; and (ii) development of appropriate methods. It is quite difficult to obtain cloud-free chronology of remote sensing data over the entire growing season of rice crop due to weather conditions (i.e., humidity, cloud, and rainy conditions), which sometimes limit the availability and make acquisition problematic. Also, the availability of the satellite data must be assured. The development of image classification methods must be effective, efficient, and easy to implement. Based on the literature, upcoming satellites such as future MODIS and the RADARSAT constellation will enhance the temporal, spectral, and spatial resolutions that could be a good fit in mapping rice areas and forecasting its production. 


\section{Acknowledgments}

We would like to thank National Sciences and Engineering Research Council (NSERC) of Canada for providing a Discovery Grant to Quazi K. Hassan.

\section{Conflicts of Interest}

The authors declare no conflict of interest.

\section{References}

1. Khush, G.S. What it will take to feed 5.0 billion rice consumers in 2030. Plant Mol. Biol. 2005, 59, $1-6$.

2. FAO. Production. Rice Market Monit. 2014, XVII, 1-10. Available online: http://www.fao.org/3/a-i4147e.pdf (accessed on 2 November 2014).

3. FAOSTAT. Available online: http://faostat.fao.org/site/377/DesktopDefault.aspx?PageID=377\#ancor (accessed on 1 November 2014).

4. FAO. FAO Statistical Yearbook 2012; FAO: Rome, Italy, 2012; pp. 214-280. Available online: http://www.fao.org/docrep/015/i2490e/i2490e03d.pdf (accessed on 2 November 2014).

5. GeoHive-Historic, Current and Future Population: Asia. Available online: http://www.geohive.com/earth/his_proj_asia.aspx (accessed on 2 November 2014).

6. Ray, D.K.; Mueller, N.D.; West, P.C.; Foley, J.A. Yield trends are insufficient to double global crop production by 2050. PLoS One 2013, 8, e66428.

7. Mohantay, S. Trends in global rice consumption. Rice Today 2013, 12, 44-45.

8. Purevdorj, M; Kubo, M. The future of rice production, consumption and seaborne trade: Synthetic prediction method. J. Food Distrib. Res. 2005, 36, 250-259.

9. IPCC. Climate Change 2014: Synthesis Report; IPCC Fifth Assessment Synthesis Report; IPCC: Geneva, Switzerland, 2014; p. 116. Available online: http://www.ipcc.ch/pdf/assessment-report/ ar5/syr/SYR_AR5_LONGERREPORT.pdf (accessed on 2 November 2014).

10. Wheeler, T.; von Braun, J. Climate change impacts on global food security. Science 2013, 341, 508-513.

11. Reynolds, C.A.; Yitayew, M.; Slack, D.C.; Hutchinson, C.F.; Huete, A.; Petersen, M.S. Estimating crop yields and production by integrating the FAO crop specific water balance model with real-time satellite data and ground-based ancillary data. Int. J. Remote Sens. 2000, 21, 3487-3508.

12. Prasad, A.K.; Chai, L.; Singh, R.P.; Kafatos, M. Crop yield estimation model for Iowa using remote sensing and surface parameters. Int. J. Appl. Earth Obs. Geoinf. 2006, 8, 26-33.

13. Bala, S.K.; Islam, A.K.M.S. Estimation of Potato Yield in and around Munshiganj Using Remote Sensing NDVI Data; Institute of Water and Flood Management: Dhaka, Bangladesh, 2008; p. 79.

14. Noureldin, N.A.; Aboelghar, M.A.; Saudy, H.S.; Ali, A.M. Rice yield forecasting models using satellite imagery in Egypt. Egypt. J. Remote Sens. Space Sci. 2013, 16, 125-131.

15. Chen, C.; Quilang, E.J.P.; Alosnos, E.D.; Finnigan, J. Rice area mapping, yield, and production forecasting for the Province of Nueva Ecija using RDARSAT imagery. Can. J. Remote Sens. 2011, $37,1-16$. 
16. National Bureau of Statistics of China (NBS). Available online: http://www.stats.gov.cn/english/ (accessed on 10 December 2014).

17. Central Statistical Office of India. Available online: http://mospi.nic.in/Mospi_New/site/ inner.aspx?status $=2 \&$ menu_id=92 (accessed on 12 December 2014).

18. Bangladesh Bureau of Statistics (BBS). Available online http://www.bbs.gov.bd/Home.aspx (accessed on 12 December 2014).

19. Tennakoon, S.B.; Murty, V.V.N.; Elumnoh, A. Estimation of cropped area and grain yield of rice using remote sensing. Int. J. Remote Sens. 1992, 13, 427-439.

20. Okamoto, K.; Fukuhara, M. Estimation of paddy field area using the area ratio of categories in each mixel of Landsat TM. Int. J. Remote Sens. 1996, 17, 1735-1749.

21. Fang, H.; Wu, B.; Liu, H.; Huang, H. Using NOAA/AVHRR and Landsat TM to estimate rice area year-by-year. Int. J. Remote Sens. 1998, 19, 521-525.

22. Xiao, X.; Boles, S.; Liu, J.; Zhuang, D.; Frolking, S.; Li, C.; Salas, W. S.; Moore, B. Mapping paddy rice agriculture in southern China using multi-temporal MODIS images. Remote Sens. Environ. 2005, 95, 480-492.

23. Xiao, X.; Boles, S.; Frolking, S.; Li, C.; Babu, J.Y.; Salas, W.; Moore, B. Mapping paddy rice agriculture in South and Southeast Asia using multi-temporal MODIS images. Remote Sens. Environ. 2006, 100, 95-113.

24. Konishi, T.; Omatu, S.; Suga, Y. Extraction of rice-planted area using a self-organizing feature map. Artif. Life Robot. 2007, 20, 215-218.

25. Gumma, M.K.; Gauchen, D.; Nelson, A.; Pandey, S.; Rala, A. Temporal changes in rice-growing area and their impact on livelihood over a decade: A case study of Nepal. Agric. Ecosyst. Environ. 2011, 142, 382-392.

26. Gumma, M.K.; Nelson, A.; Thenkabail, P.S.; Singh, A.S. Mapping rice areas of South Asia using MODIS multi-temporal data. J. Appl. Remote Sens. 2011, 5, 053547:1-053547:26.

27. Peng, D.; Huete, A.R.; Huang, J.; Wang, F.; Sun, H. Detection and estimation of mixed paddy rice cropping patterns with MODIS data. Int. J. Appl. Earth Obs. Geoinf. 2011, 13, 13-23.

28. Nuarsa, I.W.; Nishio, F.; Hongo, C. Spectral characteristics and mapping of rice plants using multi-temporal Landsat data. J. Agric. Sci. 2011, 3, 54-67.

29. Nuarsa, I.W.; Nishio, F.; Hongo, C.; Mahardika, I.G. Using variance analysis of multitemporal MODIS images for rice field mapping in Bali province, Indonesia. Int. J. Remote Sens. 2012, 33, 5402-5417.

30. Nguyen, T.T.H.; de Bie, C.A.J.M.; Ali, A.; Smaling, E.M.A.; Chu, T.H. Mapping the irrigated rice-cropping patterns of the Mekong delta, Vietnam, through hyper-temporal SPOT NDVI image analysis. Int. J. Remote Sens. 2012, 33, 415-434.

31. Lee, N.; Palsu, P. Mapping Indonesian rice area using multiple-temporal satellite imagery. Sch. J. Agric. Sci. 2012, 2, 119-155.

32. Singh, S.K.; Srivastava, P.K.; Gupta, M.; Thakur, J.K.; Mukherjee, S. Appraisal of land use/land cover of mangrove forest ecosystem using support vector machine. Environ. Earth Sci. 2014, 71, 2245-2255.

33. Yang, S.; Shen, S.; Li, B.; Le Toan, T.; He, W. Rice mapping and monitoring using ENVISAT ASAR data. IEEE Geosci. Remote Sens. Lett. 2008, 5, 108-112. 
34. Rahman, A.; Roytman, L.; Krakauer, N.Y.; Nizamuddin, M.; Goldberg, M. Use of vegetation health data for estimation of Aus rice yield in Bangladesh. Sensors 2009, 9, 2968-2975.

35. Rahman, A.; Khan, K.; Krakauer, N.Y.; Roytman, L.; Kogan, F. Use of remote sensing data for estimation of Aman rice yield. Int. J. Agric. For. 2012, 2, 101-107.

36. Wang, Y.P.; Chang, K.W.; Chen, R.K.; LO, J.C.; Shen, Y. Large-area rice yield forecasting using satellite imageries. Int. J. Appl. Earth Obs. Geoinf. 2010, 12, 27-35.

37. Huang, J.X.; Wang, X.; Li, H.; Tian, Z. Remotely sensed rice yield prediction using multi-temporal NDVI data derived from NOAA's AVHRR. PLoS One 2013, 8, e70816.

38. International Rice Research Institute (IRRI). Available online: http://www.knowledgebank.irri.org/ decision-tools/growth-stages-and-important-management-factors (accessed on 13 December 2014).

39. Rouse, J.W.; Hass, R.H.; Schell, J.A.; Deering, D.W. Monitoring vegetation systems in the Great Plains with ERTS. In Proceedings of the Third ERTS Symposium, Washington, DC, USA, 10-14 December 1973; pp. 309-317.

40. Jordan, C.F. Derivation of leaf area index from quality of light on the forest floor. Ecology 1969, 50, 663-666.

41. Huete, A.R.; Didan, K.; Miura, T.; Rodriguez, E.P.; Gao, X.; Ferreira, L.G. Overview of the radiometric and biophysical performance of the MODIS vegetation indices. Remote Sens. Environ. 2002, 83, 195-213.

42. Huete, A.R. A soil-adjusted vegetation index (SAVI). Remote Sens. Environ. 1988, 25, 295-309.

43. Zha, Y.; Gao, J.; Ni, S. Use of normalized difference built-up index in automatically mapping urban areas from TM imagery. Int. J. Remote Sens. 2003, 24, 583-594.

44. Deering, D.W.; Rouse, J.W.; Haas, R.H.; Schell, J.A. Measuring "Forage Production" of Grazing Units from Landsat MSS Data. In Proceedings of the 10th International Symposium on Remote Sensing of Environment, ERIM, Ann Arbor, MI, USA, 23-25 August 1975; pp. 1169-1178.

45. Clevers, J.P.W. The application of a vegetation index in correcting the infrared reflectance for soil background. Int. Arch. Photogramm. Remote Sens. 1986, 26, 221-226.

46. Crippen, R.E. Calculating the vegetation index faster. Remote Sens. Environ. 1990, 34, 71-73.

47. Richardson, A.J.; Wiegand, C.L. Distinguishing vegetation from soil background information. Photogramm. Eng. Remote Sens. 1977, 43, 1541-1552.

48. Gao, B.-C. NDWI-A normalized difference water index for remote sensing of vegetation liquid water from space. Remote Sens. Environ. 1996, 58, 257-266.

49. McCloy, K.R.; Smith, F.R.; Robinson, M.R. Monitoring rice areas using Landsat MSS data. Int. J. Remote Sens. 1987, 8, 741-749.

50. Shiu, Y.; Lin, M.; Huang, C.; Chu, T. Mapping paddy rice agriculture in a highly fragmented area using a geographic information system object-based post classification process. J. Appl. Remote Sens. 2012, 6, 063526:1-063526:15.

51. Fang, H. Rice crop area estimation of an administrative division in China using remote sensing data. Int. J. Remote Sens. 1998, 19, 3411-3419.

52. Huang, J.; Yaghi, A.; Wang, R. Integration of GIS and TM data to extract early rice area in Longyou County. Trans. Chin. Soc. Agric. Eng. 2001. 17, 159-162. 
53. Diuk-Wasser, M.A.; Bagayoko, M.; Sogoba, N.; Dolo, G.; Touré, M.B.; Touré, S.F.; Taylor, C.E. Mapping rice field anopheline breeding habitats in Mali, West Africa, using Landsat ETM+ sensor data. Int. J. Remote Sens. 2006, 25, 359-376.

54. Li, O.; Zhang, H.; Du, X.; Wen, N.; Tao, Q. County-level rice area estimation in southern China using remote sensing data. J. Appl. Remote Sens. 2014, 8, 083657:1-083657:16.

55. Salam, M.A.; Rahman, H. Application of remote sensing and geographic information system (GIS) techniques for monitoring boro rice expansion area in Bangladesh. Asian J. Geoinf. 2014, 14, 11-17.

56. Turner, M.D.; Congalton, R.G. Classification of muti-temporal SPOT-XS satellite data for mapping rice fields on a West African floodplain. Int. J. Remote Sens. 1998, 19, 21-41.

57. Kamthonkiat, D.; Honda, K.; Turral, H.; Tripathi, N.K.; Wuwongse, V. Discrimination of irrigated and rainfed rice in a tropical agricultural system using SPOT VEGETATION NDVI and rainfall data. Int. J. Remote Sens. 2005, 26, 2527-2547.

58. Mosleh, M.K.; Hassan, Q.K. Development of a remote sensing-based "Boro" rice mapping system. Remote Sens. 2014, 6, 1938-1953.

59. Cheng, Q.; Huang, J.F.; Wang, R.C. Assessment of rice fields by GIS/GPS-supported classification of MODIS data. J. Zhejiang Univ. Sci. 2004, 5, 412-417.

60. Sahoo, P.M.; Rai, A.; Singh, R.; Handique, B.K.; Rao, C.S. Integrated approach based on remote sensing and GIS for estimation of area under paddy crop in North-Eastern hilly region. J. Ind. Soc. Agric. Stat. 2005, 59, 151-160.

61. Lallianthanga, R.K.; Sailo, R.L.; Colney, L. Identification of potential wet rice cultivation areas in Mizoram, India: A remote sensing and GIS approach. Int. J. Geol. Earth Environ. Sci. 2013, 3, 49-56.

62. Panigrahy, S.; Chakraborty, M.; Sharma, S. A.; Kundu, N.; Ghose, S.C.; Pal, M. Early estimation of rice area using temporal ERS-1 synthetic aperture radar data-a case study for the Howrah and Hughy districts of West Bengal, India. Int. J. Remote Sens. 1997, 18, 1827-1833.

63. Kurosu, T.; Fujita, M.; Chiba, K. The identification of rice fields using multi-temporal ERS-1 C band SAR data. Int. J. Remote Sens. 1997, 18, 2953-2965.

64. Liew, S.C.; Kam, S.P.; Tuong, T.P.; Chen, P.; Minh, V.Q.; Lim, H. Application of multi-temporal ERS-2 synthetic aperture radar in delineating rice cropping systems in the Mekong River Delta, Vietnam. IEEE Trans. Geosci. Remote Sens. 1998, 36, 1412-1420.

65. Ribbes, F.; Le Toan, T. Rice field mapping and monitoring with RADARSAT data. Int. J. Remote Sens. 1999, 20, 745-765.

66. Shao, Y.; Fan, X.; Liu, H.; Xiao, J.; Ross, S.; Brisco, B.; Brown, R.; Staples, G. Rice monitoring and production estimation using multi-temporal RADARSAT. Remote Sens. Environ. 2001, 76, $310-325$.

67. Choudhury, I.; Chakraborty, M. SAR signature investigation of rice crop using Radarsat data. Int. J. Remote Sens. 2006, 27, 519-534.

68. Chen, C.; McNairn, H. A neural network integrated approach for rice crop monitoring. Int. J. Remote Sens. 2006, 27, 1367-1393.

69. Tan, C.P.; Koay, J.Y.; Lim, K.S.; Ewe, H.T.; Chuah, H.T. Classification of multi-temporal SAR images for rice crops using combined entropy decomposition and support vector machine technique. Prog. Electromagn. Res. 2007, 71, 19-39. 
70. Chen, J.; Lin, H.; Pei, Z. Application of ENVISAT ASAR data in mapping rice crop growth in southern China. IEEE Geosci. Remote Sens. Lett. 2007, 4, 431-435.

71. Wang, X.; Shi, X.; Ling, F. Images difference of ASAR data for rice crop mapping in Fuzhou, China. Geo-Spat. Info. Sci. 2010, 13, 123-129.

72. Zhang, Y.; Wang, C.; Wu, J.; Qi, J.; Salas, W.A. Mapping paddy rice with multitemporal ALOS/PALSAR imagery in southeast China. Int. J. Remote Sens. 2009, 30, 6301-6315.

73. Okamoto, K.; Kawashima, H. Estimation of rice-planted area in the tropical zone using a combination of optical and microwave satellite sensor data. Int. J. Remote Sens. 1999, 20, $1045-1048$.

74. Choudhury, I.; Chakraborty, M. Analysis of temporal SAR and optical data for rice mapping. J. Ind. Soc. Remote Sens. 2004, 32, 373-385.

75. Firouzabadi, P.Z; Sadidy, J. Paddy rice mapping of the Caspian Sea coast using microwave and optical remotely sensed data. In Proceedings of the SPIE 6359, Remote Sensing for Agriculture, Ecosystems, and Hydrology VIII, Stockholm, Sweden, 3 October 2006; Owe, M., D’Urso, G., Neale, C.M.U., Gouweleeuw, B.T., Eds.; SPIE: Bellingham WA, USA, 2006; pp. 63591A:1-63591A:10.

76. Torbick, N.; Salas, W.; Xiao, X.; Ingraham, P.; Fearon, M.G.; Biradar, C.; Zhao, D.; Liu, Y.; Li, P.; Zhao, Y. Integrating SAR and optical imagery for regional mapping of paddy rice attributes in the Poyang Lake Watershed, China. Can. J. Remote Sens. 2011, 37, 17-26.

77. Halder, D.; Patnaik, C. Synergistic use of multi-temporal Radarsat SAR and AWiFS data for rabi rice identification. J. Ind. Soc. Remote Sens. 2010, 38, 153-160.

78. Xie, Y.; Sha, Z.; Yu, M. Remote sensing imagery in vegetation mapping: A review. J. Plant Ecol. 2008, 1, 9-23.

79. Klogo, G.S.; Gasonoo, A.; Ampomah, I.K.E. On the performance of filters for reduction of speckle noise in SAR images of the coast of the Gulf of Guinea. Int. J. Inf. Technol. Model. Comput. 2013, $1,41-50$.

80. Bamler, R. Principles of synthetic aperture radar. Surv. Geophys. 2000, 21, 147-157.

81. Lillesand, T.; Kiefer, R.W. Remote Sensing and Image Interpretation, 2nd ed.; Wiley: New York, NY, USA, 1987; p. 721.

82. Shewalkar, P.; Khobragade, A.; Jajulwar, K. Review paper on crop area estimation using SAR remote sensing data. IOSR J. Electr. Electron. Eng. 2014, 9, 97-98.

83. Inoue, Y.; Kurosu, T.; Maeno, H.; Uratsuka, S.; Kozu, T.; Dabrowska-Zielinska, K.; Qi, J. Season-long daily measurements of multifrequency $(\mathrm{Ka}, \mathrm{Ku}, \mathrm{X}, \mathrm{C}$, and $\mathrm{L})$ and full-polarization backscatter signatures over paddy rice field and their relationship with biological variables. Remote Sens. Environ. 2002, 81, 194-204.

84. Patel, N.K.; Ravi, N.; Navalagund, R.R. Estimation of rice yield using IRS-1A digital data in costal tract of Orissa. Int. J. Remote Sens. 1991, 12, 2259-2266.

85. Nuarsa, I.W.; Nishio, F.; Hongo, C. Relationship between rice spectral and rice yield using MODIS data. J. Agric. Sci. 2011, 2, 80-88.

86. Son, N.T.; Chen, C.F.; Chen, C.R.; Chang, L.Y.; Due, H.N.; Nguyen, L.D. Prediction of rice crop yield using MODIS EVI-LAI data in the Mekong Delta, Vietnam. Int. J. Remote Sens. 2013, 34, 7275-7292. 
87. Nuarsa, I.W.; Nishio, F.; Hongo, C. Rice yield estimation using Landsat ETM+ data and field observation. J. Agric. Sci. 2012, 3, 45-56.

88. Li, Y.; Liao, Q.; Li, X.; Liao, S.; Chi, G.; Peng, S. Towards an operational system for regional-scale rice yield estimation using a time-series of RADARSAT ScanSAR images. Int. J. Remote Sens. 2003, 24, 4207-4220.

89. Prasad, A.K.; Singh, R.P.; Tare, V.; Kafatos, M. Use of vegetation index and meteorological parameters for the prediction of crop yield in India. Int. J. Remote Sens. 2007, 28, 5207-5235.

90. Smith, G.M.; Fuller, R.M. An integrated approach to land cover classification: An example in the Island of Jersey. Int. J. Remote Sens. 2001, 22, 3123-3142.

91. Bangladesh Bureau of Statistics (BBS). Statistical Yearbook of Bangladesh; Government of the People's Republic of Bangladesh: Dhaka, Bangladesh, 2013; p. 468.

92. Sarma, A.A.L.N.; Lakshmi Kumar, T.V.; Koteswararao, K. Development of an agro-climatic model for the estimation of rice yield. J. Ind. Geophys. Union 2008, 12, 89-96.

93. Savin, I.Y.; Isaev, V.A. Rice yield forecast based on satellite and meteorological data. Russ. Agric. Sci. 2010, 36, 424-427.

94. Inoue, Y. Synergy of remote sensing and modeling for estimating ecophysiological processes in plant production. Plant Prod. Sci. 2003, 6, 3-16.

95. Delécolle, R.; Maas, S.J.; Guerif, M.; Baret, F. Remote sensing and crop production models: Present trends. ISPRS J. Photogramm. Remote Sens. 1992, 47, 145-161.

96. Ribbes, F.; Le Toan, T. Coupling radar data and rice growth model for yield estimation. In Proceedings of the 1999 IEEE International Geoscience and Remote Sensing Symposium, Hamburg, Germany, 28 June-2 July 1999; pp. 2336-2338.

97. Kropff, M.J.; van Laar, H.H.; Matthews, R.B. ORYZA1: An ecophysiological model for irrigated rice production. DLO-Research Institute of Agrobiology and Soil Fertility: Wageningen, Netherlands, 1994; p. 110.

98. Huang, J.-F.; Tang, S.-C.; Abou-Ismail, O.; Wang, R.-C. Rice yield estimation using remote sensing and simulation model. J. Zhejiang Univ. Sci. 2002, 3, 461-466.

99. Shen, S.H.; Yang, S.B.; Li, B.B.; Tan, B.X.; Li, Z.Y.; Le, T.T. A scheme for regional rice yield estimation using ENVISAT ASAR data. Sci. Chin. Ser. D Earth Sci. 2009, 52, 1183-1194.

100. Bouman, B.A.M.; Kropff, M.J.; Tuong, T.P.; Wopereis, M.C.S.; Ten Berge, H.F.M.; van Laar, H.H. ORYZA2000: Modelling Lowland Rice; International Rice Research Institute: Los Baños, Philippines; Wageningen University and Research Center: Wageningen, The Netherlands, 2001; p. 235.

101. Guo, J., Wang, Q.; Zheng, T.; Li, X.; Shi, J.; Zhu, J. Estimation of rice yield based on integration remote sensing information and crop model. In Proceedings of the SPIE 8513, Remote Sensing and Modelling of Ecosystems for Sustainability IX, San Diego, CA, USA, 12 August 2012; Gao, W., Jackson, T.J., Wang, J., Chang, N.-B., Eds.; SPIE: Bellingham WA, USA, 2012; pp. 85130F:1-85130F:10.

102. Dadhwal, V.K.; Ray, S.S. Crop assessment using remote sensing-Part II: Crop condition and yield assessment. Ind. J. Agric. Econ. 2000, 55, 55-67.

103. Liu, W.T.; Kogan, F. Monitoring Brazilian soybean production using NOAA/AVHRR based vegetation condition indices. Int. J. Remote Sens. 2002, 23, 1161-1179. 
104. Hijmans, R.J.; Cameron, S.E.; Parra, J.L.; Jones, P.G.; Jarvis, A. Very high resolution interpolated climate surfaces for global land areas. Int. J. Clim. 2005, 25, 1965-2005.

105. Chilés, J.-P.; Delfiner, P. Geostatistical Modeling Spatial Uncertainty, 2nd ed.; Wiley: Hoboken, NJ, USA, 2012; p. 699.

106. Palosuo, T.; Christian Kersebaum, K.; Angulo, C.; Hlavinka, P.; Moriondo, M.; Olesen, J.E.; Patil, R.H.; Ruget, F.; Rumbaur, C.; Takac, J.; et al. Simulation of winter wheat yield and its variability in different climates of Europe: A comparison of eight crop growth models. Eur. J. Agron. 2011, 35, 103-114.

107. IPCC. Climate Change 2007: Synthesis Report; IPCC Fourth Assessment Synthesis Report; IPCC: Valencia, Spain, 2007; p. 52. Available online: http://www.ipcc.ch/pdf/assessment-report/ar4/syr/ ar4_syr.pdf (accessed on 10 October 2014).

108. Basak, J.K.; Ali, M.A.; Islam, M.N.; Rashid, M.A. Assessment of the effect of climate change on boro rice production in Bangladesh using DSSAT model. J. Civ. Eng. 2010, 38, 95-108.

109. Martinelli, F.; Scalenghe, R.; Davino, S.; Panno, S.; Scuderi, G.; Ruisi, P.; Villa, P.; Stroppiana, D.; Boschetti, M.; Goulart, L.R.; et al. Advanced methods of plant disease detection. A review. Agron. Sustain. Dev. 2014, doi:10.1007/s13593-0140246-1.

(C) 2015 by the authors; licensee MDPI, Basel, Switzerland. This article is an open access article distributed under the terms and conditions of the Creative Commons Attribution license (http://creativecommons.org/licenses/by/4.0/). 